\title{
How conceptualisations of curriculum in higher education influence student-staff co-creation in and of the curriculum
}

\author{
Catherine Bovill $^{1}$ (D) $\cdot$ Cherie Woolmer ${ }^{2}$
}

Published online: 26 December 2018

(C) The Author(s) 2018

\begin{abstract}
There is a wide range of activity taking place under the banner of 'co-created curriculum' within higher education. Some of this variety is due to the different ways people think about 'co-creation', but significant variation is also due to the ways in which higher education curriculum is conceptualised, and how these conceptualisations position the student in relation to the curriculum. In addition, little attention is paid to the differences between co-creation of the curriculum and co-creation in the curriculum. This paper addresses this gap by examining four theoretical frameworks used to inform higher education curriculum design. We examine how each framework considers the position of the learner and how this might influence the kinds of curricular co-creation likely to be enacted. We conclude by calling for more discussion of curriculum and curriculum theories in higher education - and for these discussions to include students. We argue that more clarity is needed from scholars and practitioners as to how they are defining curriculum, and whether they are focused on co-creation of the curriculum or co-creation in the curriculum. Finally, we suggest that paying greater attention to curriculum theories and their assumptions about the learner, offers enhanced understanding of curricular intentions and the extent to which collaboration is possible within any particular context.
\end{abstract}

Keywords Curriculum · Curriculum theory $\cdot$ Co-creation · Partnership · Student agency

Catherine Bovill

Catherine.bovill@ed.ac.uk

1 Institute for Academic Development, University of Edinburgh, 1 Morgan Lane, Edinburgh EH8 8FP, UK

2 McPherson Institute for Leadership Innovation and Excellence in Teaching, McMaster University, Mills Memorial Library, 1280 Main Street, Hamilton, Ontario L8S 4L6, Canada 


\section{Introduction}

There has been a surge of interest in students and staff co-creating curricula in the last 5 to 10 years, but this is not a new idea. Indeed, Dewey argued for more democratic approaches to curriculum at the beginning of the twentieth century (Bovill 2013; Dewey 1916). In the 1980s, questions about who defines the curriculum gained further traction through the development of critical pedagogy. Critical pedagogy challenges the continued teaching of accepted forms of knowledge and encourages students and staff to collaborate in creating new forms of knowledge from their own experiences, in order to question existing views of the world (Darder et al. 2003; Giroux 1981). Whilst critical pedagogy was focused predominantly on school education, it has influenced higher education (Crowther et al. 2005). In higher education, authors have argued that curricula need to focus more upon learning processes rather than just outcomes, and that curricular structures need to include space for innovation, creativity and ensuring relevance to learners (Bovill 2017a; Bron et al. 2016; Knight 2001). One way of achieving this is by providing opportunities for students to co-create curricula with staff. Bovill et al. (2016: 196) define co-creation as occurring '...when staff and students work collaboratively with one another to create components of curricula and/or pedagogical approaches'.

Author one is highly influenced by critical pedagogy and a background in international development, and author two from her encounters as a first generation student and academic. However, whilst many colleagues are influenced by the desire to develop more democratic classrooms, many others are motivated to co-create curricula due to the range of benefits increasingly being evidenced. Others are motivated by the emphasis institutions are placing on student engagement in order to raise scores in the UK National Student Survey or equivalent surveys. We believe that co-creating the curriculum can reframe the learning spaces in universities by enabling the co-construction of knowledge; redressing traditional hierarchies between teacher and learner; and developing new forms of what Fielding (1999) describes as radical collegiality, which are necessary to counter the increasing commodification of learning. Literature about co-creating curricula records how the process of co-creation enhances engagement, motivation, identity development, meta-cognitive understanding of learning and teaching, self-authorship abilities and can lead to improved assessment performance (CookSather et al. 2014; Lubicz-Nawrocka 2018). Although the benefits of co-created curriculum are increasingly being evidenced, Bovill et al. (2016: 195) have highlighted some of the challenges faced in co-creation, namely 'overcoming resistance, navigating institutional norms and ensuring inclusivity'. In addition, co-creation is often considered time intensive and risky (Bovill 2014; Marquis 2018). Yet despite these challenges, Ryan and Tilbury (2013) argue, learner engagement through co-creation needs to be at the core of new flexible pedagogies, and many consider the democratic reframing of learning spaces to be urgently needed. Opportunities to co-create curricula are inherently influenced by individual perceptions of curriculum and of students in relation to knowledge and pedagogy. We agree with Ashwin and McVitty's (2015: 351) assertion that ' ...the question of students exercising agency in their own learning [is] a profoundly moral one.'

There are many different ways in which researchers and practitioners have been co-creating curricula. In some examples, students lead the design of courses from scratch (Woolmer et al. 2016), in others, students design the curriculum as a course progresses (Cook-Sather et al. 2014). Mihans et al. (2008) describe students working alongside staff on curriculum design committees, and Rock et al. (2015) describe co-creation within curriculum approval systems. How we think about curriculum has a direct influence upon what we are inviting students to 
co-create and yet, there is an absence of curriculum theory in much of the current co-created curriculum literature. There are likely to be a number of reasons for this: the relative silence about curriculum more generally in higher education; the small body of literature that specifically addresses curriculum theory in higher education; and a reluctance to use the term curriculum due to confusion about what it means. We propose that the ways we think about curriculum impact upon our perceptions of the possibilities and scope for involving students, the focus of any co-creation, and ultimately upon the learning experience of students.

The teacher's attitude, motivations and outlook are critical to co-creation. It is the teacher who provides the cues to students as to what kind of relationship is being established and about any opportunities for co-creation. Academic staff remain the gatekeepers of curriculum (Bourner 2004; Bovill 2014) and staff therefore need to pay explicit attention to how their conceptualisation of curriculum informs any potential co-creation.

\section{Co-creation of the curriculum and in the curriculum}

In higher education, the absence of debate about curriculum (Barnett and Coate 2005), contributes to confusion and assumptions about the opportunities for, and understandings of, curriculum co-creation. Although co-creation activity appears to be centred in particular countries (mainly the UK, USA, Canada, Scandinavia and Australia), the range of research and practice taking place is vast and incorporates small and large-scale initiatives as well as curricular and, slightly confusingly, extracurricular initiatives, ${ }^{1}$ co-design and co-research of learning, teaching and assessment. Co-creation activity also rarely distinguishes between what Bovill et al. (2016) describe as co-creation of the curriculum (co-design of a programme or course, usually before the programme or course takes place) and co-creation in the curriculum (co-design of learning and teaching within a course or programme usually during the course or programme). An example of co-creation of the curriculum comes from Elon University, in the USA, where a small number of future students who were about to study a course and a small group of retrospective students who had already studied the course, collaborated with course faculty and colleagues from the Center for Teaching and Learning, to form a curriculum planning team to design course content and processes (Bovill 2014; Mihans et al. 2008). An example of co-creation in the curriculum comes from Reading University, in the UK, where a professor in Classics invites students to design their own essay titles based on six to eight key words, enabling students to steer the focus of their essay. The professor discusses proposed titles with students to ensure the scope is appropriate for the length and level of essay required (Cook-Sather et al. 2014).

We argue that developing a deeper understanding of how curriculum is conceptualised in higher education can help us to be more explicit about what we are inviting students to cocreate and ultimately, may influence the types of co-creation that are possible. In this article, we outline four curriculum frameworks that have either been devised specifically within higher education or which are increasingly applied to higher education curricula. We examine the ways in which each of these theories positions students as potential co-creators and

\footnotetext{
${ }^{1}$ The term co-created curriculum is commonly misused to describe co-creation of co-curricular or extracurricular activity. In some cases, this may be explained by some confusion over the terms co-created curriculum and cocurriculum, but in many other instances, there is a curious oxymoron where people are using the term co-created curriculum to refer to collaborative extracurricular initiatives outside academic curricula.
} 
contributors to knowledge. We then discuss how these framings can help to identify opportunities to co-create curricula. This article complements other literature examining student engagement with curriculum, which suggests that students not only engage with, but have the potential to change, that with which they engage (Ashwin and McVitty 2015).

\section{Higher education curriculum conceptualisations}

Barnett and Coate (2005) have argued that higher education curriculum ${ }^{2}$ in the UK has not received as much attention as might be expected for a concept that underpins university learning and teaching. Many influential concepts have informed debates about higher education curriculum, for example, threshold concepts (Meyer and Land 2003), signature pedagogies (Shulman 2005), approaches to learning and studying (Marton and Saljo 2005), disciplinary knowledge (Becher and Trowler 2001; Maton 2013; Shay 2013), and assessment of, for and as learning (Earl 2003). Some of these concepts are referred to in this article but, whilst connected, we see them as distinct from, other existing, models and frameworks that focus specifically on curriculum conceptualisation and design.

We focus on the key frameworks that dominate the relatively limited discussions about higher education curriculum: Biggs' (1996) constructive alignment model; Fraser and Bosanquet's (2006) academic staff definitions of higher education curriculum; Barnett and Coate's (2005) Knowing, acting and being framework; and Bernstein's $(1975,2000)$ work on 'what counts as valid knowledge' and 'framing'. We outline some of the key ideas from each of these frameworks in turn and how each of them positions students. These models and frameworks differ in the extent to which they are conceptual or applied as well as in the ways in which they have influenced debate and practice about higher education curriculum. For example, we have chosen to include Bernstein's theory of what counts as valid knowledge despite this theory not being designed with higher education curricula in mind. Bernstein's ideas are rooted in an important sociological critique of power and inequality in schools curriculum (an important concern for cocreated curricula), and have had important but limited application within higher education practice (see for example, Abbas et al. 2016; Clarence-Fincham and Naidoo 2014). Conversely, Bigg's model of constructive alignment is perhaps simpler and less theoretically based, and has been widely adopted in higher education as a practical curriculum design tool, easily understood and implemented by academics who are not sociologists or educational theory specialists. We acknowledge that all the models make significantly different contributions to the field and offer helpful lenses through which to explore how adopting a particular conceptualisation can impact on the opportunities for co-creation of the curriculum and co-creation in the curriculum. For the purposes of our discussion, we seek to describe the models rather than offering a judgement about which have the greatest utility more broadly. As with all frameworks, it is how they are used and interpreted that determines any possible outcomes. We realise that our interpretations might differ from others' perspectives on these theories.

\footnotetext{
${ }^{2}$ Although we refer to both curriculum (singular) and curricula (plural), we understand that in most universities around the world, multiple curricula are designed in different disciplines for different stages of study. There may be a common foundational curriculum taught in, for example, liberal arts colleges in the USA, but most universities will deal with multiple curricula.
} 


\section{Constructive alignment (Biggs 1996)}

John Biggs (based in the UK, Australia and Hong Kong at different times in his career) proposed the constructive alignment model, which has been highly influential for higher education curriculum design worldwide. Biggs' intention with constructive alignment is to shift from a teacher-focused to student-focused curriculum and ensure all elements of the curriculum are coherent. The term 'constructive' refers to the constructivist theory of education where learners create and construct knowledge and meanings by making sense of and assimilating new experiences and information in relation to their existing knowledge. The term 'alignment' refers to ensuring that all the elements of curriculum design are inter-linked. Curriculum developers start by designing the broad aims and intended learning outcomes for a course before considering how students will be assessed on their achievement of the intended learning outcomes. As Ashwin et al. (2015: 161) describes 'we are, through learning outcomes, attempting to move away from a focus on teaching, what we do, to a focus on learning, what the student does'. The early focus on assessment mirrors many students' assessmentmotivated orientation to studying and is echoed in Wiggins and McTighe's (2006) backwards curriculum design approach. The assessment aligns with teaching methods and with the evaluation of the curriculum, so that all elements are coherent. Biggs (1996: 350) argues that teaching 'forms a complex system embracing, at the classroom level, teacher, students, the teaching context, student learning activities, and the outcome; the classroom system is then nested in a larger institutional system'.

The focus on outcomes in the constructive alignment model is not without its critics, and many have argued that it suggests a curriculum that is neatly linear and that prioritises outcomes over the process of learning (Knight 2001). Constructive alignment can lead academic staff to focus at the level of the course or module, although the approach is also used at the programme level. The popularity of Biggs' model within higher education institutions worldwide may relate to the increasing focus within quality assurance systems on using learning outcomes as transparent indicators of the curriculum offer. The focus on learning outcomes enables universities to state the specific (and more generic) knowledge and skills that students should develop by the end of their courses, programmes and degrees to meet the needs of the employment market. The logic of this kind of model can be refreshing where the alternative has often been a lack of transparency about curriculum expectations. However, constructive alignment does not guarantee transparent and high-quality curricula. In some disciplines, there is a tendency to proliferate content-focused learning outcomes, and in others the strong emphasis on skills for meeting employment needs can overpower the need for students to develop the ability to undertake critical inquiry into specialist knowledge. The emphasis on predefined outcomes can also lead to a lack of space for spontaneous learning.

\section{Academic staff definitions of curriculum (Fraser and Bosanquet 2006)}

Australian researchers, Fraser and Bosanquet, undertook phenomenographic research to examine academic staff definitions of curriculum. Staff were found to hold four main curricular understandings: 'A: the structure and content of a unit (subject); B: the structure and content of a programme of study; $\mathrm{C}$ : the students' experience of learning; $\mathrm{D}$ : a dynamic and interactive process of teaching and learning' (Fraser and Bosanquet 2006: 272). Definitions A and B are recognisable to most people and are similar to one another but distinguished by a focus on different levels and scope of curriculum design. In contrast, definition $\mathrm{C}$ could be considered 
more student-centred and the authors describe definition D as involving an integral role for students in designing and enacting curriculum alongside academic staff.

Categories A and B suggest a rational linear model of curriculum, comparable to Biggs' notion of constructive alignment, where content and process are decided by the academic. Categories $\mathrm{C}$ and $\mathrm{D}$ provide examples of more process-oriented curriculum. Fraser and Bosanquet describe these categories as '...moving away from curriculum as a product provided for students, to a process that enables student learning' (p274). In category C, '...students are the centre of a flexible curriculum process, and are able to explore with their teachers areas that suit their needs and motivations' (p274), they go on to explain that '...curriculum change and development occurs as an ongoing dialogue between teachers and students, framed by the more holistic understandings of the teacher' (p175). Academic staff who define curriculum as the students' experience of learning, report finding it difficult to discuss curriculum with colleagues who consider the curriculum in terms of content and structure. Fraser and Bosanquet highlight that 'consequently, process-focused curriculum change is often implemented by individuals in isolation, without posing a significant challenge to existing product and structural understandings of curriculum' (p275).

Finally, Fraser and Bosanquet (2006) describe category D ' as a collaborative process of learning, with teacher and student acting as co-constructors of knowledge' (p275). They point out that it differs from category $\mathrm{C}$, '... where teachers provide a framework within which students negotiate the curriculum. Here, the structure of the learning experience is not predetermined or defined; rather, it emerges from the needs of the students and the interactions between students, teachers and colleagues' (p275). They explain that teachers holding this particular conceptualisation see the goal of any curriculum as empowering students to become effective members of society, challenging students' (and staff) assumptions and changing their views of the world.

\section{Knowing, acting and being (Barnett and Coate 2005)}

Barnett and Coate's (2005) curriculum framework, based on empirical research carried out in the UK, calls for a balance to be achieved between knowing, acting and being. The idea of 'acting' focuses less on application of knowledge as is often thought, but rather on something that Entwistle (2003) and McCune and Hounsell (2005) described as 'ways of thinking and practising' (WTP) in the subject. This is the range of practices and approaches that are often tacit within disciplines, but which are crucial to becoming, for example, a doctor (rather than simply knowing medical knowledge required to pass an exam). When Barnett and Coate refer to 'being', they talk of the development of the student as a person, and that this development should encompass the idea of students' sense of being-in-the-world. They argue that current views of curriculum that focus on content and skills development are insufficient to meet the complex needs of the twentyfirst century. They suggest that '...students as such are only minimally implicated in this dominant conception of curricula. They come into play only as potential bearers of skills producing economic value rather than as human beings in their own right' (Barnett and Coate 2005: 24). For Barnett and Coate, curriculum '...is dynamic and in flux and is also the site of contested interpretations. A curriculum is fluid and is not - cannot - be caught in any schema or template.' (p51). This echoes those academics in Fraser and Bosanquet's study who defined curriculum within category $\mathrm{D}$, and who found the term curriculum too constraining. 
Barnett and Coate describe the variations in the attention given to each of these critical areas of curriculum within different disciplines. In their research, they found that the arts and humanities tended to pay most attention to knowing, followed by being and then acting. In science and technology subjects, knowing was again the primary focus, followed by acting, and finally being. In contrast, in professional subjects, attention was given foremost to acting, with knowing and being given less, but relatively similar levels of attention.

We mentioned that Barnett and Coate's (2005) concept of 'acting' relates to both Entwistle's work and McCune and Hounsell's work on ways of thinking and practising (WTP) in a subject (Entwistle 2003; McCune and Hounsell 2005), but both of these ideas also relate to Lee Shulman's 'signature pedagogies' (Shulman 2005). Shulman argues that different professions adopt approaches to teaching that have distinctive and distinguishing characteristics. He uses the examples of law (and the forms of often aggressive direct questioning of students that replicate the forms of exchange in the courtroom) and medicine (with interactive exchange focused on cases that take place in bedside ward rounds) to illustrate how signature pedagogies teach not just the knowledge of the discipline, but also the ways in which students need to act to become a lawyer or a doctor. Shulman, in the same year of publication as Barnett and Coate, argues that pedagogy must balance the attention given to all dimensions of professional practice '...the intellectual, the technical, and the moral' (Shulman 2005: 58).

\section{What counts as valid knowledge and 'framing' (Bernstein 1975, 2000)}

Sociologist Basil Bernstein's work has been highly influential in shaping thinking about school curriculum. More recently, Bernstein's work has been influencing higher education curriculum thinking, particularly in South Africa and Australia, but also amongst a small group of scholars in the UK. Bernstein considered the curriculum as defining '... what counts as valid knowledge' (Bernstein 1975: 85), and '...pedagogy what counts as valid transmission of knowledge... '(Goodson 2001: 166). 'Framing' was how Bernstein referred to the '... strength of the boundaries within pedagogical relationships...strongly framed classroom interactions include the traditional lecture format, with students listening and taking notes. In contrast, other types of courses can be weakly framed, as students take on different and more ambiguous roles in the classroom' (Barnett and Coate 2005: 34).

Bernstein (2000) proposed that the choices made in any curriculum highlight what counts as valid knowledge. These choices focus on selection (the content of the curriculum), sequencing (what order/progression), pacing (how much time/credit), and evaluation (what counts for assessment). These choices tend to legitimate certain practices over others. Bernstein also discussed the idea of a pedagogic device - based on three fields of discourse - the field of production where new knowledge is created, the field of recontextualisation where knowledge is transformed into the curriculum, and reproduction where knowledge is taught to students.

Many of the current scholars referencing Bernstein's work are focused on ensuring knowledge is at the core of curriculum (Maton 2013; Young 2013; Ashwin 2014). Based on Bernstein's ideas, Maton has developed Legitimation Code Theory (LCT) to explore the organising principles within knowledge (Maton 2013). One aspect of LCT is 'specialisation' which analyses what aspects of knowledge make it distinct. Specialisation codes provide a sense of whether disciplines focus relatively more upon possession of specialised knowledge, skills or procedures, or whether the dispositions of actors as 'knowers' are emphasised. The different emphasis within subjects can help to explain particular disciplinary environments, 
and what counts as important, and this in turn shapes disciplinary curricula (Becher and Trowler 2001). Building on Bernstein's work, Shay (2013) provides a sophisticated argument for the importance of analysing the connections between theoretical and practical knowledge within curricula in order to ensure access to socially powerful knowledge as well as ensuring the balance between theoretical and practical knowledge is fit for purpose for specific differentiated curricula.

\section{How do curricular conceptualisations influence co-creation?}

The four curriculum framings we have presented demonstrate a variety of ways in which curriculum is conceptualised, and each speak to different aspects of the intellectual, technical and moral dimensions of curriculum and pedagogy (Shulman 2005). Bovill et al. (2016) proposed that students adopt one or more of four roles in co-creating learning and teaching: (1) representative, (2) consultant, (3) co-researcher and (4) pedagogical co-designer. The nature of co-creation is changed by the role students adopt, and it's likely that particular curricular conceptualisations influence the co-creation roles open to students. There are distinct differences between the role of a student who is elected to be a class representative, several students selected by interview to become co-researchers, and students selected to become consultants observing, discussing and giving feedback on academics' teaching. Different again is the teacher undertaking co-creation in the curriculum with an entire class of students. Adding to the complexity, roles can be fluid in practice, with students occupying different roles at different times as work evolves (Bovill 2017b). This leads us to consider the question of how curricular conceptualisations position students and influence possibilities for co-creation.

Biggs' model has been influential in shifting emphasis towards curriculum design that pays explicit attention to student learning and what the students does. However, this framework assumes that the teacher retains responsibility for identifying learning outcomes and the ways in which assessment, teaching and evaluation will align, and it does not address issues of power and privilege in the production of knowledge. This system-based approach can appear so tightly bound that it unintentionally limits flexibility and possibilities for student-staff co-creation. Although Biggs' model shifts the focus towards the learner, it does not easily create opportunities for co-creation in the curriculum, if most university structures require learning outcomes and assessments to be explicitly determined prior to the course/programme commencing (Huxham et al. 2015). Yet, the model's widespread use and perceived rigidity has led to some creative responses. Even in professionally accredited programmes that have a range of specific outcome and competence requirements, staff and students have found space to co-create the ways in which outcomes are achieved. In some situations, academic staff have collaborated with students in designing outcomes and assessment rubrics (Deeley \& Bovill 2017; Gibson 2011), thereby enabling co-creation of the curriculum and students adopting a pedagogical codesigner role. Huxham et al. (2015: 534) reject constructive alignment's 'focus on the design activities by the tutor and its strong emphasis on predetermined outcomes', and argue for more flexibility in curriculum development. Employing a mountaineering metaphor; they outline a process of students and staff co-navigating the 'natural lines' of a course and moving away from notions of the curriculum as a pre-set, bounded system. Perhaps, the most commonly associated student co-creation role in the constructive alignment model is that of representative, who raises issues on behalf of other students at staff-student liaison committee meetings or in other settings in the hope that staff will amend courses and programmes in response to their feedback. 
Within Fraser and Bosanquet's work, there is a wide range of different curriculum conceptualisations. In definitions A and B, many staff are still thinking about curriculum in ways that may restrict the possibilities for co-created curriculum, where the focus on structure and content positions students as recipients of a preset, codified, curriculum. Category $\mathrm{C}$ suggests a move towards enhancing interaction and negotiation within the framework of a predefined curriculum. This is an example of co-creation in the curriculum where the teacher provides students with some structure and choices. Category D implies that the relationship between the teacher and students changes fundamentally to one where the curriculum is a dynamic and interactive collaboration. There are perhaps fewer examples of this kind of curriculum, but a whole cohort of students working alongside a teacher to make choices and design their own curriculum in action illustrates this approach (see, for example Bovill et al. 2010; Huxham et al. 2015; Stoddard et al. 2012). This conceptualisation could refer to cocreation of the curriculum or co-creation in the curriculum depending upon the stage that students are involved, and particularly in category $\mathrm{C}$ and $\mathrm{D}$, students are likely to adopt many of the co-creation roles, but particularly student consultant, co-researcher and pedagogical codesigner roles. In Fraser and Bosanquet's study, many staff adopting a category D definition of curriculum often preferred not to use the term curriculum at all. There is a clear division between what we might describe as rational, pre-set and linear definitions of curriculum (categories A and B) and emergent and discursive definitions (categories C and D), with the potential for very different opportunities for students to exercise choice, influence learning and to co-construct knowledge and pedagogy.

Barnett and Coate's framing of knowing, acting and being calls for the holistic development of students within disciplines. However, the authors also distinguish between curriculumdesign-in-advance and curriculum-design-in-action. They describe the latter as 'inescapably a relational matter' (Barnett and Coate 2005: 131), and this is close to the concept of co-creation in the curriculum. Their model does not explicitly address the extent to which students can or should influence curriculum-design-in-advance, but their model relies on students bringing their existing experience to the curriculum and there being opportunities for students to develop their sense of identity further through developing a 'stance' in relation to knowledge and their place in the world. Therefore, when adopting this model, there is an implication that the student must be involved meaningfully and the curriculum must be made relevant to the student, her ideas, experiences and aspirations. An example of this approach in Scotland comes from a Social Justice course at Queen Magaret University, Edinburgh, which has involved providing a curricular framework within which students bring issues of social injustice from their own communities, around which a curriculum is then co-designed (Bovill 2014; Samson and Scandrett 1999). The disciplinary differences that are highlighted between the relative emphases placed on knowing, acting and being, suggest that opportunities for co-creating the curriculum may be different across the disciplines. Indeed, whether particular disciplinary curricula are more suited and open to co-creation is an area that would benefit from further research. Nevertheless, there are excellent examples of co-created curriculum emerging from many disciplines. Barnett and Coate's curriculum framework might involve students as representatives, co-researchers and pedagogical co-designers, depending upon the relative openness of academic staff to adapt to more collaborative forms of curriculum design and pedagogy.

Of the four framings explored in this article, Bernstein's approach is most abstract but it is also the only model to explicitly address power in the process of knowledge (re)production. The position of students is not explicitly addressed; yet, the centrality of knowledge and notions of validity in this curriculum framing raise pressing questions about who determines 
this validity and where there might be spaces for students to bring their knowledge and expertise to interact with the processes of knowledge production, recontextualisation and reproduction. The idea that only some knowledge is considered 'valid', appears to challenge the possibility of inclusivity or co-construction of knowledge, and Bernstein's interpretation of pedagogy as 'transmission of valid knowledge' suggests a model of teaching far from the negotiation and relational teaching required for co-creation in the curriculum. Bernstein's argument that the curriculum represents valid knowledge, suggests a highly predetermined curriculum that ensures that hegemonic ideas are replicated. In a similar way to the critiques of Biggs' constructive alignment model, others have disregarded this notion of predetermined valid knowledge, instead opening up curricular knowledge to negotiation. For example, at Elon University, Mihans et al. (2008) describe how students questioned the value of the set text book for an education course. They questioned what counted as valid knowledge, and this ultimately led to a collaborative process of renegotiating a more suitable course text through a process of co-creation of the curriculum. Relatively weaker framing within some disciplines (similar to the disciplinary differences noted above by Barnett \& Coate) suggests that there might be greater potential for co-creation in the curriculum. Where knowledge construction is considered open to student contribution, students may adopt a role of co-researcher or pedagogic co-designer, but how open the Bernsteinian framing of curriculum is to student influence, is debatable.

The key characteristics of each curricular framework, implications for possible co-created curriculum, and the co-creation roles most likely to be associated with each framework are summarised and presented in Table 1. We acknowledge that individual academics can always subvert and reinterpret frameworks, resulting in entirely different possibilities emerging.

\section{Theory into practice: the importance of context}

These frameworks have the potential to influence academic staff as to whether and how they engage students in co-creating curriculum, but the extent to which these frameworks are influential depends greatly upon whether particular staff are aware of the different curriculum frameworks. In addition, the specific context influences what kinds of co-created curriculum might be envisaged as possible and desirable (Bovill and Bulley 2011).

The wider societal context within which universities operate also influences curriculum. As Shay and Peseta (2016: 362) argue, we need to question '...in what ways do our curricula give access to the powerful forms of knowledge that students require not only to successfully complete their degrees, but also to participate fully in society?'. In addition, Shay and Peseta (2016) highlight that the social realists' agenda of defending the place of knowledge in the curriculum has perhaps led them to overlook who sets the knowledge agenda in the curriculum. Indeed, it is perhaps worth noting the irony of the continued reliance on Bernstein's (white, male) curricular theories within much of the current discussion of decolonising the curriculum in South Africa. The dominant use of Bernstein by a particular group of sociologists in English medium universities to inform curriculum debate in South Africa has been described by Le Grange (2014: 473) as 'insular' and 'unreflexive'. Consequently, while these scholars are furthering important debate on higher education curriculum around the central notion of knowledge and decolonisation, it is with limited engagement of colleagues charged with designing curricula in other disciplinary areas. On the one hand, whichever theories and whoever's interests are dominating curricular discourse will have a significant impact on the 
Table 1 Overview of curricular frameworks

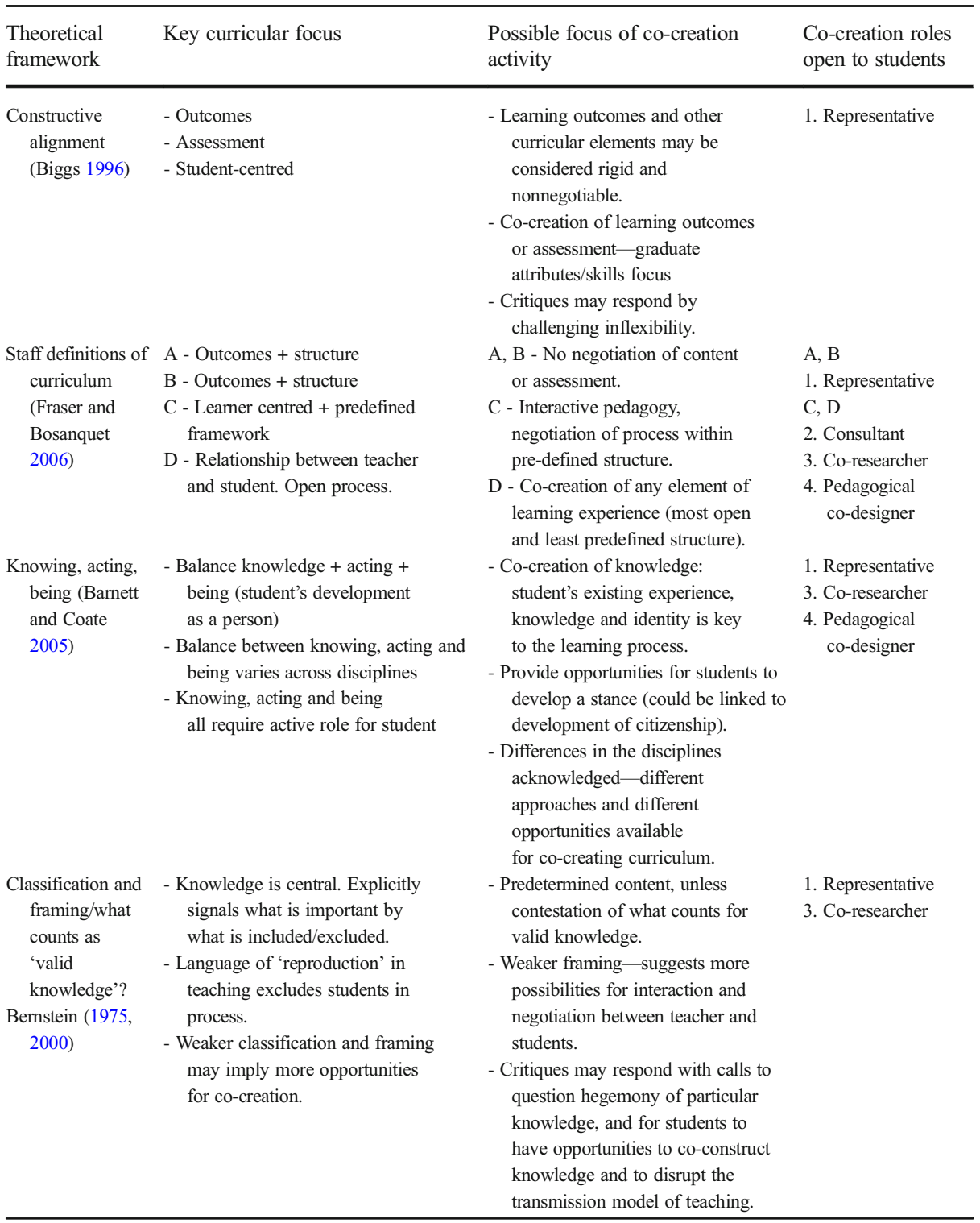

opportunities that are available for students to co-create curricula. On the other hand, cocreation of and in the curriculum have the potential to bring new voices and perspectives into discussion of curricula and to challenge existing ways of thinking about knowledge and curriculum.

Curriculum is understood and mediated within disciplinary and institutional cultures, and under the scrutiny of institutional quality assurance mechanisms. Indeed, there can be a substantial gap between the intended curriculum and the enacted curriculum due to a 
wide range of influencing factors at micro, meso, and macro levels within an institution. Barnett and Coate (2005: 71) describe the 'zones of influence' which act upon curriculum, including internal and external pressures from the academic community, practical, epistemological and ontological considerations as well as varying beliefs about the purpose of higher education. Similarly, Jenkins (2009: 163) describes how curriculum is exposed to a number of pushes and pulls at any time: 'faculty seek to control, shape, and prioritize these 'forces' in terms of their own and their students' interests'.

This situation is further complicated by the existence of what has been described as the 'hidden curriculum' or the tacit rules of curriculum engagement that are not outlined in official documents. Barnett and Coate (2005: 34) argue 'those students who can make sense of the unwritten rules of learning, teaching and assessment in higher education are those who will benefit most from their learning experiences'. This is important, as it highlights several key considerations for co-creating curriculum: students may not understand what the curriculum is (or the particular version of curriculum envisaged by the teacher); some students may be excluded from co-creation if we do not pay attention to inclusivity; and as Mann (2001) argues, we may unintentionally support or make worse student alienation if we do not pay attention to the ways in which we create barriers to student engagement in and with the curriculum.

Many higher education teachers feel pressured by how they can possibly fit all the required content into the curriculum, and this can lead to an 'overstuffed curriculum'. This seems to be more of an issue in particular disciplines, perhaps reflecting the way 'foundational' knowledge is conceptualised, and this in turn may be viewed as limiting space for curriculum co-creation. Time constraints, professional body requirements, individual pedagogic habits of mind, and the relationship between staff and students are just some of the contextual factors that will influence co-creation (Cook-Sather et al. 2014). Academic staff who consider the curriculum in terms of Fraser and Bosanquet's category D or in terms of Barnett and Coate's balance between developing knowing, acting and being, are perhaps best placed to conceive of co-created curriculum possibilities, because students are considered integral to the curriculum process and to knowledge co-creation.

\section{Implications for practice: breaking the silence}

One way in which we could 'break the silence' about curriculum, which Barnett and Coate (2005) highlighted, would be to find or establish spaces for discussion about curriculum, and about learning and teaching in the academy. Roxå and Mårtensson (2009) draw attention to the benefits of enhancing informal learning and teaching networks and conversations, and building on this work, Woolmer et al. (2017) have explored the benefits of extending these informal networks and conversations to include students. Where, in our current committees and networks, do we discuss our curricular perspectives and how our values are enacted in our pedagogical practice? Our examination of four conceptualisations of curricula and how they each position students provides a starting point for this collective debate. The table presented in Table 1 is intended to be a heuristic that could facilitate these kinds of discussions - a place for academic and professional services staff and students to begin to discuss their tacit beliefs about curriculum.

Academic staff make many of the initial decisions about co-created curriculum based on their curriculum perspectives before students are invited into the process, such as 
which students are invited in; the focus on course or programme level curriculum; the focus on processes, structure, content or outcomes; and the nature of any co-creation (Bovill 2014). Academic staff are considered experts and therefore often decide what is inside or outside of any negotiation process - what is up for debate and what is off bounds. As Ashwin and McVitty argue, 'academic staff retain protected territory into which student voice is unwelcome...' (Ashwin \& McVitty: 350). What perhaps needs further exploration is the extent to which protected territories are closed to negotiation for well-considered reasons, or whether traditions, habits and institutional structures are limiting curriculum dialogue. Pedagogy and curriculum design need academic staff expertise, but there is a danger of perpetuating hegemonic forms of knowledge and creating irrelevant curricula if we exclude student perspectives. Indeed, it is only though articulating our understanding of curriculum in a given context, that students and academics can be clear about the parameters for negotiation. This holds true for any of the theoretical positions presented in this article.

\section{Conclusion}

Further dialogue about curriculum in higher education is needed, as it would: (1) help individuals examine their espoused and enacted beliefs about curricula in their contexts, (2) make explicit the scope of possibilities for students to participate in cocreation of the curriculum and co-creation in the curriculum, and (3) clarify how cocreating curriculum is distinct from other activities described within the students as partners literature (such as work relating to extra-curricular initiatives). Cook-Sather et al. (2014: 33) argue that shared respect, reciprocity and responsibility are key principles to underpin partnership in learning and teaching. These principles sit in contrast to curricular conceptualisations where curriculum is 'done to' students, but they also provide a set of values that could guide co-creation of and in the curriculum.

Greater clarity is important if we are to build a deeper understanding of co-created curriculum and if we are to be more transparent with students about what we are inviting them to be part of. It will help to build evidence of what specific forms of co-created curriculum can offer. Returning to Fraser and Bosanquet's research, some academic staff reported finding it difficult to talk about curriculum with colleagues where there existed ingrained understandings of what curriculum is. So, we need to develop both clarity about our own conceptualisations of curriculum whilst remaining respectful and open to alternative curriculum ideas held by others.

The context within which a curriculum is developed and experienced is key to what might be possible. Where staff are new to the idea of co-creation, it may be wise to take small steps towards co-creating the curriculum in the first instance (Cook-Sather et al. 2014). Indeed, we recommend taking time to create conversations with colleagues more experienced in co-created curriculum, to become more aware of the different ways in which curriculum is talked about and the different ways in which students and staff are collaborating. This will help to build confidence and broaden visions of what is possible. Moving towards more collaborative forms of curriculum is not straightforward or risk free, as we hope we have demonstrated in this article, but it is necessary if we are to achieve more democratised learning spaces in higher education. 
Open Access This article is distributed under the terms of the Creative Commons Attribution 4.0 International License (http://creativecommons.org/licenses/by/4.0/), which permits unrestricted use, distribution, and reproduction in any medium, provided you give appropriate credit to the original author(s) and the source, provide a link to the Creative Commons license, and indicate if changes were made.

\section{References}

Abbas, A., Ashwin, P., \& McLean, M. (2016). The influence of curricula content on English sociology students' transformations: the case of feminist knowledge. Teaching in Higher Education, 21(4), 442-456.

Ashwin, P. (2014). Knowledge, curriculum and student understanding in higher education. Higher Education, $67(2), 123-126$.

Ashwin, P., Boud, D., Coate, K., Hallett, F., Keane, E., Krause, K.-L., et al. (2015). Reflective teaching in higher education. London: Bloomsbury.

Ashwin P. \& McVitty D. (2015). The meanings of student engagement: implications for policies and practices. In: A. Curaj, L. Matei, R. Pricopie, J. Salmi, \& P. Scott (Eds.), The European Higher Education Area. (pp. 343359). Springer. https://link.springer.com/book/10.1007/978-3-319-77407-7 Accessed 13 October 2017.

Barnett, R. \& Coate, K. (2005). Engaging the curriculum in higher education. Maidenhead: Open University Press.

Becher, T. \& Trowler, P. (2001). Academic tribes and territories: intellectual enquiry and the culture of the disciplines (Second edition). Buckingham: Society for Research into Higher Education / Open University Press.

Bernstein, B. (1975). Class, codes and control: towards a theory of educational transmission. London: Routledge.

Bernstein, B. (2000). Pedagogy, symbolic control and identity: theory, research, critique. Lanham, MD: Rowman \& Littlefield.

Biggs, J. (1996). Enhancing teaching through constructive alignment. Higher Education, 32(3), 347-364.

Bourner, T. (2004). The broadening of the higher education curriculum, 1970-2002: an ipsative enquiry. Higher Education Review, 36(2), 39-52.

Bovill, C. (2017a). Breaking down student-staff barriers: moving towards pedagogic flexibility. In I. Kinchin \& N. E. Winstone (Eds.), Pedagogic frailty and the University (pp. 151-161). Rotterdam: Sense Publishers.

Bovill, C. (2017b). A framework to explore roles within student-staff partnerships in higher education: which students are partners, when and in what ways?. International Journal for Students as Partners 1 (1) 1-5. https://mulpress.mcmaster.ca/ijsap/article/view/3062/2770 Accessed 5 July 2018.

Bovill, C. (2014). An investigation of co-created curricula within higher education in the UK, Ireland and the USA. Innovations in Education and Teaching International, 51(1), 15-25.

Bovill, C. (2013). Students and staff co-creating curricula - a new trend or an old idea we never got around to implementing? In C. Rust (Ed.), Improving Student Learning through research and scholarship: 20 years of ISL (pp. 96-108). Oxford: The Oxford Centre for Staff and Educational Development.

Bovill, C., Aitken, G., Hutchison, J., Morrison, F., Roseweir, K., Scott, A., \& Sotannde, S. (2010). Experiences of learning through collaborative evaluation from a postgraduate certificate in professional education. International Journal for Academic Development, 15(2), 143-154.

Bovill, C., \& Bulley, C. J. (2011). A model of active student participation in curriculum design: exploring desirability and possibility. In C. Rust (Ed.), Improving student learning (18) (pp. 176-188). Oxford: OCSED.

Bovill, C., Cook-Sather, A., Felten, P., Millard, L., \& Moore-Cherry, N. (2016). Addressing potential challenges in co-creating learning and teaching: overcoming resistance, navigating institutional norms and ensuring inclusivity in student-staff partnerships. Higher Education, 71(2), 195-208.

Bron, J., Bovill, C., \& Veugelers, W. (2016). Students experiencing and developing democratic citizenship through curriculum negotiation: the relevance of Garth Boomer's approach. Curriculum Perspectives, 36(1), 15-27.

Clarence-Fincham, J., \& Naidoo, K. (2014). Translating theoretical perspectives into constructive debate: reconceptualising the curriculum in the South African context. South African Journal of Higher Education, 28(3), 1003-1016.

Cook-Sather, A., Bovill, C. \& Felten, P. (2014). Engaging students as partners in learning and teaching: a guide for faculty. San Francisco: Jossey Bass.

Crowther, J., Galloway, V., \& Martin, I. (2005). Introduction: radicalising intellectual work. In J. Crowther, V. Galloway, \& I. Martin (Eds.), Popular education: engaging the academy. International perspectives (pp. 17). Leicester: Niace.

Darder, A., Baltodano, M., \& Torres, R. D. (2003). Critical pedagogy: an introduction. In A. Darder, M. Baltodano, \& R. D. Torres (Eds.), The critical pedagogy reader (pp. 1-21). New York: RoutledgeFalmer. 
Deeley, S., \& Bovill, C. (2017). Staff-student partnership in assessment: enhancing assessment literacy through democratic practices. Assessment and Evaluation in Higher Education, 42(3), 463-477.

Dewey, J. (1916). Democracy and education: an introduction to the philosophy of education. New York: The Macmillan Company.

Earl, L. (2003). Assessment as learning: using classroom assessment to maximise students learning. Thousand Oaks: Corwin Press.

Entwistle, N. (2003). Concepts and Conceptual Frameworks Underpinning the ETL Project. (Occasional Reports, 3) Edinburgh: University of Edinburgh, Enhancing Teaching-Learning Environments in Undergraduate Courses Project.

Fielding, M. (1999). Radical collegiality: affirming teaching as an inclusive professional practice. Australian Educational Researcher, 26(2), 1-34.

Fraser, S., \& Bosanquet, A. (2006). The curriculum? That's just a unit outline, isn't it? Studies in Higher Education, 31(3), 269-284.

Gibson, L. (2011). Self-directed learning: an exercise in student engagement. College Teaching, 59(3), 95-101.

Giroux, H.A. (1981). Hegemony, resistance and the paradox of educational reform. In H.A. Giroux, A.N. Penna, and W.F. Pinar (Eds.), Curriculum and instruction alternatives in education. (pp. 407-429). Berkerley: McCutchen Publishing.

Goodson, I. F. (2001). Basil Bernstein 1925-2000. In J. A. Palmer, L. Bresler, \& D. Cooper (Eds.), Fifty modern thinkers on education from Piaget to the present. London: Routledge.

Huxham, M., Hunter, M., McIntyre, A., Shilland, R., \& McArthur, J. (2015). Student and teacher co-navigation of a course: following the natural lines of academic enquiry. Teaching in Higher Education, 20(5), 530-541.

Jenkins, A. (2009). Supporting student development in and beyond the disciplines: the role of the curriculum. In C. Kreber (Ed.), The university and its disciplines: teaching and learning within and beyond disciplinary boundaries (pp. 157-168). Abingdon: Routledge.

Knight, P. (2001). Complexity and curriculum: a process approach to curriculum-making. Teaching in Higher Education, 6(3), 369-381.

Le Grange, L. (2014). Curriculum research in South Africa. In W. F. Pinar (Ed.), International handbook of curriculum research (pp. 466-475). Abingdon: Routledge.

Lubicz-Nawrocka, T. M. (2018). From partnership to self-authorship: the benefits of co-creation of the curriculum. International Journal for Students as Partners, 2(1), 47-63.

McCune, V., \& Hounsell, D. (2005). The development of students' ways of thinking and practising in three final year biology courses. Higher Education, 49(3), 255-289.

Mann, S. J. (2001). Alternative perspectives on the student experience: alienation and engagement. Studies in Higher Education, 26(1), 7-19.

Marquis, E. (2018). Embracing and/or avoiding the risks of partnership: a faculty perspective. Teaching and Learning Together in Higher Education, 1(24). https://repository.brynmawr.edu/tlthe/vol1/iss24/9 Accessed 8 August 2018.

Marton, F. \& Saljo, R. (2005). Approaches to learning. In F. Marton, D. Hounsell, \& N. Entwistle (Eds.), The experience of learning: implications for teaching and studying in higher education. 3rd (internet) edition (pp. 39-58). Edinburgh: University of Edinburgh Centre for Teaching Learning and Assessment.

Maton, K. (2013). Knowledge and knowers: towards a realist sociology of education, London: Routledge.

Meyer, J. H. F., \& Land, R. (2003). Threshold concepts and troublesome knowledge (1): linkages to ways of thinking and practising. In C. Rust (Ed.), Improving student learning - ten years on (pp. 412-424). Oxford: OCSLD.

Mihans, R., Long, D. \& Felten, P. (2008). Student-faculty collaboration in course design and the scholarship of teaching and learning. International Journal for the Scholarship of Teaching and Learning, 2(2). https://digitalcommons.georgiasouthern.edu/ij-sotl/vol2/iss2/ Accessed 8 August 2018.

Rock, R., Foster, E. \& Lamb, S. (2015). Putting students at the heart of the curriculum change process. York: Higher Education Academy.

Roxå, T., \& Mårtensson, K. (2009). Significant conversations and significant networks: exploring the backstage of the teaching arena. Studies in Higher Education, 34(5), 547-559.

Ryan, A., \& Tilbury, D. (2013). Flexible pedagogies: new pedagogical ideas. York: Higher Education Academy. https://www.heacademy.ac.uk/sites/default/files/resources/npi_report.pdf Accessed 13 July 2018.

Samson, S., \& Scandrett, E. (1999). Environmental citizenship and environmental justice. Friends of the Earth Scotland's Catalyst Project. Concept, 9(2), 26-27.

Shay, S. (2013). Conceptualizing curriculum differentiation in higher education: a sociology of knowledge point of view. British Journal of Sociology of Education, 34(4), 563-582.

Shay, S., \& Peseta, T. (2016). A socially just curriculum reform agenda. Teaching in Higher Education, 21(4), 361-366.

Shulman, L. S. (2005). Signature pedagogies in the professions. Daedalus, 134(3), 52-59. 
Stoddard, I., Rieser, I., Andersson, S., \& Friman, E. (2012). Igniting a learning revolution: student-run higher education for sustainable development. The Solutions Journal, 3(5), 34-39.

Wiggins, G., \& McTighe, J. (2006). Understanding by design (2nd ed.). New Jersey: Pearson.

Woolmer, C., Sneddon, P., Curry, G., Hill, B., Fehertavi, S., Longbone, C., \& Wallace, K. (2016). Student-staff partnership to create an interdisciplinary science skills course in a research-intensive university. International Journal for Academic Development, 21(1), 16-27.

Woolmer, C., Marquis, B. \& Bovill, C. (2017). Exploring the relationship between significant networks and faculty-student partnerships: beyond partnership-as-initiative. Paper presentation, ISSOTL Conference, Calgary, Canada, 12-14 October.

Young, M. (2013). Overcoming the crisis in curriculum theory: a knowledge-based approach. Journal of Curriculum Studies, 45(2), 101-118. 